\title{
FOR GOD SO LOVED THE WORLD
}

The Reverend Dr. Andrew Linzey

Chaplain and Director of Studies

Centre for the Study of Theology

University of Essex. England

\section{Sermon preached in Salisbury Cathedral Service for Animal Welfare Saturday 15 Octaber 1988}

Imagine a scene. The date is the 18 April, 1499. The time is sometime in the afternoon. The place is the Abbey of Josaphat, near Chartres. Within this Abbey a trial is taking place. It is a criminal prosecution before the Bailiff of the Abbey. The defendant is charged with having killed an infant. The verdict is announced. The defendant is found guilty. The sentence of the ecclesiastical court is that the defendant should be hanged. Mercifully, unlike other defendants, the fate is only death and not torture or mangulation. And the defendant was hanged by its neck at a public hanging that day in the market square. The defendant, however, was not a human being, but a pig.

What is the point of recounting this grisly, surely altogether extraordinary episode from the 15th century, you may ask? The answer is this: grisly it certainly was, extraordinary it certainly was not. From the 9th to the 19th century we have over 200 written accounts of the criminal prosecution and capital punishment of animals. These trials of animals, pigs, dogs, wolves, locusts, rats, termites, cows, horses and doves inflicted great and terrible suffering. And the important thing to appreciate is that these trials were mainly or wholly religious in character. They drew their inspiration from Christian doctrine, based on a silly biblical fundamentalism - a fundamentalism I'm distressed to say is still with us in some quarters of the Church today. In particular it was St. Thomas Aquinas in his Summa Theologiae

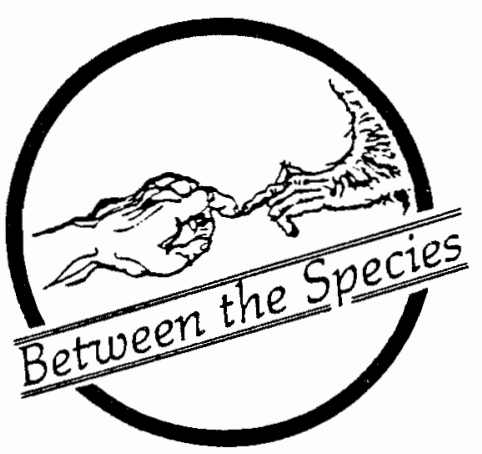

who held that some animals were satellites of Satan: "instigated by the powers of hell and proper to be cursed?" St. Thomas added: "the anathema then is not to be pronounced against the animals as such, but should be hurled inferentially at the devil who makes use of irrational creatures to our detriment."

Armed with this awful dictum (however originally qualified by St. Thomas) Christians have spent more than 10 centuries anathematizing, cursing and reviling the animal world. The echoes of this violence are found today in our very language. The word 'animal' is a term of abuse, not to mention 'brute,' 'beast' or 'bestial.' How we have libelled the animal world. For myself I cannot but be bemused by the reference in the marriage service of the Book of Common Prayer to "brute beasts which hath no understanding." Who are these brute beasts? Most higher mammals seem to know more about life-long monogamy than many buman beings.

This low, negative, even hating, attitude towards animals, regarding them as a source of evil, or as instruments of the devil, or regarding them as beings without any moral status, has, sad to say, been the dominant view within Christendom for the largest part of its history. In the 9th century, Pope Stephen IV prepared great quantities of holy water with which to anathematize hordes of locusts. In the 19th century, Pope Pius IX forbade the opening of an animal protection office in

(C) copyright A. Linzey, 1988

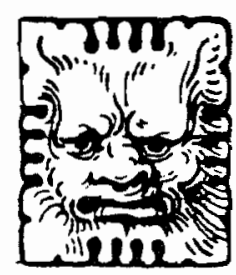

RELIGION 
Rome on the grounds that humans had duties to other humans, but none to animals. For a clear run of at least 10 centuries the dominant ecclesiastical voice did not even regard animals as worthy of moral concern. We do well to remember that Catholic textbooks still regard animals as morally without status, save when they are deemed human property. Worse than that, they have been frequently classified as things without rights, to be used -- as St. Thomas himself wrote -- "in any way whatever." If Jesus can weep over Jerusalem we have more than good reason to weep over the sins of Mother Church.

It seems to me that there is no use pretending that all has been well with the Church either in the past, or even now in the present. The very community which should be the cradle of the Gospel of God's Love for the world has only been too good at justifying violence and legitimizing hatred towards the world. Those like myself who have the temerity to preach to Christian and non-Christian alike, must be quite clear that the record of Christianity has been, and still is, on this issue as on many others, in many respects shameful and second rate. Christians are simply too good at forgetting how awful they have been. The fact is that Christians have had enormous difficulties in believing their own Gospel.

And what is this Gospel? It is nothing less than the conviction and experience that God loves the whole world. What we see in Jesus is the revelation of an inclusive, all-embracing, generous Loving. A Loving that washes the feet of the world. A Loving that heals individuals from oppression - physical and spiritual. A Loving that take sides with the poor, vulnerable, diseased, hated, despised, and outcasts of his day. A Loving that is summed up in his absolute commitment to love at all costs even in extreme suffering and death. As that distinguished former Dean of Salisbury, Sydney Evans, once wrote: "What Jesus did on the Cross was to demonstrate the truth of what he had taught: he showed a quality of love such that the worst that evil could do to such love was to give such love ever fresh opportunities for loving."

The world we live in is desperate for love. The whole world needs to be loved. When I was young I used to mock the notion of "Gentle Jesus, meek and mild." How wrong I was! For there is great power in humility, strength in gentleness, wisdom in forbearance. We need to listen again to Father Zossima's advice in Dostoyevsky's The Brothers Karamazov:

Brothers, be not afraid of men's
sins. Love man even in his sin,
for that already bears the
semblance of divine love and is
the highest love on earth. Love
all God's creation, the whole of
it and every grain of sand. Love
every leaf, every ray of God's
light! Love the animals, love the
plants, love everything. And if
you love everything you will
perceive the divine mystery in
things. And once you have
perceived it, you will begin to
comprehend it ceaselessly more
and more every day. And you
will at last come to love the
whole world with an abiding,
universal love.

Not all Christians have been happy with this Gospel. While God's love is free, generous and unlimited, we Christians have only been too good at placing limits on Divine Love. St. Thomas Aquinas was a great scholar and saint, but even he believed quite erroneously that God did not love animals for their own sakes, but only in so far as they were of use to human beings. We Christians have at various times made of this Revelation of Unlimited Love its precise opposite. We have conceived of this Revelation in exclusive terms, exclusive of one group or race: those who were non-Jews, those who are women, those who are coloured, and so on. Not all Christians have seen how the love of God gives each individual human being a unique and equal value. But at least we can say that these issues have been on the agenda of the Churches. Not so with other suffering non-human creatures. What has not been seen is that the love of God is inclusive not only of humans but also all creatures. It took Christians many years to realize that we cannot love God and keep humans as slaves. It has taken 
even longer for Christians to realize that we cannot love God and regard women as second class humans. Now is the time for Christians to realize that we cannot love God and hate his nonhuman creatures. Christians are people who need to be liberated by the Gospel they preach. Christians cannot love God and be free to hate.

For people, like myself, who are concerned for justice in our dealings with animals there are three things we must learn.

The first is that we must not hate even those who hate animals. "Do not be afraid of men's sins," writes Dostoyevsky. People who work for justice for animals are often disappointed, angry, unhappy people, and more often than not with just cause. It is incredible that we should treat God's creatures with so little love and respect; incredible that we should despoil animal life for fun and amusement; incredible that we should wantonly slaughter; incredible that we should make wild animals captive for entertainment; incredible that we should inflict suffering and pain on farm and laboratory animals. It is spiritually infantile that we should continue to look upon the world as "made for us" and animals simply as means to human ends, as resources, as tools, as machines, indeed simply as things. And yet we must not hate those who hate God's world. By doing so we simply push them further into their own abyss and spiritual darkness. All of us need to be loved, all of us need interior resources to go on loving. And all this is very, very hard especially when we see creatures treated so cruelly that their cause cries to heaven for justice. But we have one real and lasting weapon at our disposal: 'Soul-force.' As Dostoyevsky writes: "Loving humility is a terrible force, the strongest of all ...(with it we shall) conquer the world." So I don't want to hate anybody, even vivisectors, butchers, trappers, factory farmers and bullfighters. On the contrary I want to love them so much that they will not find time, or have the inclination, to hunt, and kill, and destroy and maim God's good creatures. I refuse to give those who exploit animals another good reason for not believing in a God of love.

Secondly, we must not hate, even the Church. I know that this is very difficult, not least of all because the Church has a lamentable record on animals and, what is more, is still a party to animal cruelty. 1 say now, and have said privately in the past, to the Church Commissioners that the time has come when in the name of God most loving they must stop allowing factory farming (and also hunting) on their owned lands. Christians, even Church Commissioners, must be signs of the Gospel for which all creatures long. I know that the Church is not always very lovable to say the least. But I also say to you that we shall not advance the cause of animals by hating the Church. On the contrary we must love it so much that it repents of its theological foolishness, its far too frequent humanist arrogance and its complicity in sins against animals. But I say to you that hatred is too great a burden to bear.



I want to give you one example that should give us hope. If we go back in history 200 years or so, we will find intelligent, respectable, conscientious Christians for whom slavery was not a moral issue. If pressed some might have defended slavery as 'progress' as many thought it was. Some might even have taken the view of William Henry Holcombe writing in 1860 that slavery was a natural means of "the Christianization of the dark races." The quite 
staggering fact to grapple with is that this very same community which in some ways provided the major ideological impetus for the defence of slavery came within an historically short period. 100 , perhaps only 50 , years to change its mind. The same tradition which helped keep slavery alive was the same community that became by and large determined to end it. So successful has this change been that within this congregation today we shall have difficulty in finding one slave trader, even one individual Christian who thought that the practice was anything other than inimical to the moral demands of the Christian faith. In short, while it is true that Christian churches have been and frequently are awful on the subject of animals, it is just possible, even plausible that given say 50 or 100 years we shall witness among this same community amazing shifts of consciousness as we have witnessed on other moral issues, no less complex or controversial. Christian Churches then have been agents of oppression - that is commonplace - but they can also be agents of liberation.

We do well in this context to remember and honour all those courageous Christians: saints, and seers, theologians and poets, mystics and writers who have championed the cause of animals. The list must include almost two thirds of those canonized saints East and West, not only St. Francis but also St. Martin, Richard of Chichester, Chrysostom, Isaac the Syrian, Bonaventure, and countless others. Poets also like Rosetti, Browning, Carlyle, Longfellow, Hardy, Cowper, and the many others who have led the way in sensitivity to the animal world. And if we are to be grateful for these luminaries, then one name especially must be mentioned, namely Arthur Broome. Few people appreciate that it was this Anglican priest who founded the first animal welfare society in the world, the RSPCA, in 1824. Fewer people appreciate that this Society was the result of Christian inspiration and vision. Even fewer appreciate that this Society was founded specifically on "Christian Faith and Christian Principles." Broome's work was immensely sacrificial. He served the Society as its first secretary; he gave up his London living to work full-time for the Society, he suffered imprisonment for the Society's debts, and finally died in obscurity. The animal movement today would be nowhere if it was not for this one man's courage and Christian faith. Long may his name be honoured among those who work for the cause of animals.

And there are just one or two hints today that Christians are again waking up to the idea that God's creation must not be reviled, anathematized and treated as evil as in the past.

"[P|reoccupation with humanity will seem distinctly parochial ...our theology ... has been distorted by being too man-centered. We need to maintain the value, the preciousness of the human by maintaining the value, the preciousness of the non-human also." These words are not mine. They come from no less a person than the Archbishop of Canterbury, Robert Runcie, speaking in April of this year. He went on:

"For our concept of God forbids the idea of a cheap creation, of a throwaway universe in which everything is expendable save human existence. The whole universe is a work of love. And nothing which is made in love is cheap. The value, the worth of natural things is not found in Man's view of himself but in the goodness of God who made all things good and precious in his sight..." As Barbara Ward used to say, "We have only one earth. Is it not worth our love?"

These words may have cost our Archbishop more than we imagine. Let us congratulate him on his testimony and take heart.

The third thing we must learn is that we must not hate one another. It is no use people like me in the animal rights movement - complaining about animal abusers and the churches for their lack of love and compassion - when we so often show so little love and compassion to one another. I can give personal testimony here. I spent 4 years on the ruling council of one of the largest animal welfare societies in this country and 10 or more years later I am still trying to heal the wounds I suffered. The animal movement is the place where we can find as much if not more sin than anywhere else. Jealously, rivalry, misquotation, guile, stupidity, and, worst of all, self-righteousness. We must not fall into this last trap especially. None of us is pure when it comes to animals. We are all involved in animal abuse either through the food we eat, the products we buy, or the taxes we pay. There is no pure land on earth. A clean conscience is a figment of the 
imagination. I spend some of my time counselling students who suffer from unrelieved feelings of guilt - often inculcated by the Churches - I have no desire to make anyone feel guilty. Guilt is a redundant emotion.

Christians in the animal movement have a unique opportunity. St. Paul speaks of the creation as in a state of childbirth awaiting a new age. Together we have vision of a new age, a new world. A world at peace, a world in which we have begun to make peace with creation. A world in which the Love of God is claimed and championed and through whose Spirit new world possibilities are constantly being opened up for us. What a difference it would make if Christians began to practice the Gospel of Love they preach. At the very least what we need to do is to encourage and inspire people to live free of injury to animals. All of us, in addition to whatever social vision we may have, need a programme of personal disengagement from injury to animal life.

Let me be personal for a moment. I haven't always been an advocate of animal rights. By no means. When I was young I used to enjoy controlling animals and making them captive. I used to enjoy fishing. I used to eat animals. I had no problems about eating veal. My entry into the animal rights movement coincided with my entry into a slaughterhouse when I was 16 years old. The questions that it raised in my mind have been with me ever since. Recently, during my speaking tour of the United States, I visited another slaughterhouse in the State of Mašsachusetts. As I stood watching a young pig being slaughtered -'stuck' as they say in the US -

I asked myself this question: "What has changed in 26 years when animals are still treated as things?" And soon I had my answer: the owner of the slaughterhouse, despite the fact that I had asked permission in the usual way, turfed me out. I'm not used to being turfed out of places. It was a new experience and a valuable one. For I learnt this one thing: What is changing is that many people, even those intensely involved in the exploitation of animals, many people are not so sure as they once were that what they are doing is right. People are beginning to have a conscience even in the most unlikely places.

When I became intellectually convinced of the case for animal rights, I first thought it one of those important but comparatively minor questions in Christian ethics. I don't think that today. On the contrary, I think the question of how we treat animals one of the BIG questions confronting all humanity: if God loves and cares for this world, shall we learn to live at peace with one another and with this world? In short: Are we to hate the world or are we to love it? "We must love one another or die," wrote W.H. Auden. The truth we also have to learn is this: We must love the world, or we shall perish with it.

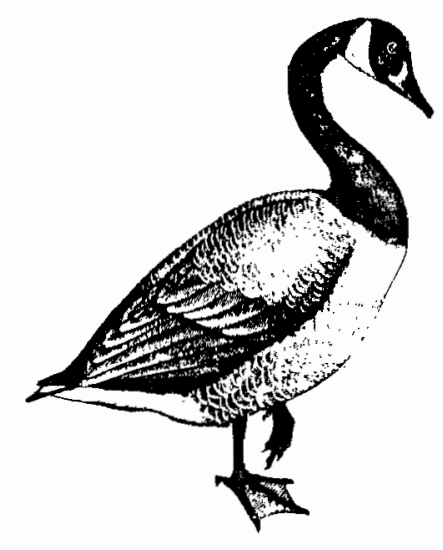

NOYEMBER

\section{OF THE CANADA GEESE}

\author{
Beautiful children \\ of the Northern Lights. \\ Perhaps untamed, runaway stars. \\ Seasons of black and white wonder \\ against the sky. \\ Nobility of spirit; \\ each one faithful \\ to the love of his life. \\ Autumn sun rises \\ on another bewildered dreamer \\ falling in a sudden profanity \\ of gunshot.
}

- Kathleen Malley 